\title{
PENGEMBANGAN PERANGKAT PEMBELAJARAN FISIKA BERBASIS PROBLEM BASED LEARNING (PBL) PADA MATERI HUKUM NEWTON DAN PENERAPANNYA KELAS X SMAN 2 MEJAYAN
}

\author{
Susdarwati ${ }^{1}$, Sarwanto $^{2}$, Cari $^{3}$ \\ ${ }^{1}$ Magister Pendidikan Sains, Fakultas Keguruan dan Ilmu Pendidikan, Universitas Sebelas Maret \\ Surakarta, 57126, Indonesia \\ susdarwati82ppsuns@gmail.com \\ ${ }^{2}$ Magister Pendidikan Sains, Fakultas Keguruan dan Ilmu Pendidikan, Universitas Sebelas Maret \\ Surakarta, 57126, Indonesia \\ Sarwanto.fkip.uns@gmail.com \\ ${ }^{3}$ Magister Pendidikan Sains, Fakultas Keguruan dan Ilmu Pendidikan, Universitas Sebelas Maret \\ Surakarta, 57126, Indonesia \\ carinln@yahoo.com
}

\begin{abstract}
Abstrak
Penelitian ini bertujuan untuk: 1) menghasilkan produk perangkat pembelajaran Fisika SMA berbasis Problem Based Learning (PBL) pada materi hukum Newton dan penerapannya kelas X SMAN 2 Mejayan dengan karakteristik kurikulum 2013,2) menganalisis kelayakan perangkat pembelajaran Fisika SMA berbasis Problem Based Learning (PBL) pada materi hukum Newton dan penerapannya kelas X SMAN 2 Mejayan, dan 3) meningkatkan aktivitas belajar siswa kelas X SMAN 2 Mejayan menggunakan perangkat pembelajaran Fisika SMA berbasis Problem Based Learning (PBL). Penelitian ini merupakan Research and Development (R\&D) dengan menggunakan model 4-D meliputi tahapan define, design, develop, dan disseminate yang dikemukakan oleh Thiagarajan. Perangkat pembelajaran yang dikembangkan berupa RPP, Lembar Penilaian Kinerja, dan LKS dengan pedoman pada Permendikbud RI nomor 103 tahun 2014 tentang Kurikulum 2013 Sekolah Menengah Atas/Madrasah Aliyah serta Permendikbud RI nomor 104 tahun 2014 tentang penilaian hasil belajar oleh pendidik pada Pendidikan Dasar dan Pendidikan Menengah. Pengumpulan data prestasi belajar siswa pada kompetensi sikap, pengetahuan, dan keterampilan dalam penelitian ini menggunakan lembar penilaian kinerja dan aktivitas belajar siswa menggunakan lembar observasi. Hasil penelitian menunjukkan bahwa: 1) perangkat pembelajaran Fisika SMA berbasis Problem Based Learning (PBL) pada materi hukum Newton dan penerapannya kelas X SMAN 2 Mejayan dengan karakteristik kurikulum 2013 dikembangkan berdasarkan komponen pembelajaran scientific dengan model Problem Based Learning (PBL) disertai metode percobaan menggunakan teori belajar Bruner, Konstruktivisme, dan Piaget, 2) perangkat pembelajaran berbasis Problem Based Learning (PBL) pada materi hukum Newton dan penerapannya kelas X SMAN 2 Mejayan layak digunakan dengan kategori sangat baik berdasarkan (a) hasil penilaian validasi oleh dosen ahli, guru, dan peer review, (b) hasil penilaian siswa terhadap pembelajaran pada uji coba terbatas dan uji coba lapangan, dan (c) hasil penilaian guru pada tahap penyebaran, 3) implementasi perangkat pembelajaran berbasis Problem Based Learning (PBL) pada uji coba lapangan menunjukkan bahwa aktivitas belajar siswa kelas X SMAN 2 Mejayan mengalami peningkatan sebesar $13,17 \%$.
\end{abstract}

Kata kunci: Perangkat Pembelajaran, PBL.

\section{Pendahuluan}

Peraturan Pemerintah Republik Indonesia nomor 32 tahun 2013 pasal 19 ayat 3 yang berkaitan dengan standar proses mengisyaratkan bahwa pendidik pada setiap satuan pendidikan diharapkan melakukan perencanaan proses pembelajaran, pelaksanaan proses pembelajaran, penilaian hasil pembelajaran, dan pengawasan proses pembelajaran untuk terlaksananya proses pembelajaran yang efektif dan efisien. Hal ini 
mensyaratkan bagi pendidik pada satuan pendidikan untuk mengembangkan perencanaan pembelajaran. Setiap guru pada satuan pendidikan berkewajiban menyusun perangkat pembelajaran secara lengkap dan sistematis agar pembelajaran berlangsung secara interaktif, inspiratif, menyenangkan, menantang, memotivasi peserta didik untuk berpartisipasi aktif, serta memberikan ruang yang cukup bagi siswa untuk mengembangkan aktivitas, kreativitas, dan kemandirian sesuai dengan bakat, minat, dan perkembangan fisik serta psikologis siswa. Proses pembelajaran yang bermutu terkait dengan kesiapan guru dalam membuat rencana pembelajaran yang baik untuk memastikan bahwa pemilihan metode yang tepat, ketersediaan media, penilaian yang mencakup sikap, pengetahuan, dan keterampilan, dan siswa dapat saling bersinergi untuk menciptakan pembelajaran bermakna yang berpedoman pada kurikulum yang digunakan.

Implementasi kurikulum 2013 mengharuskan guru mengembangkan atau menyusun perangkat pembelajaran dengan menyesuaikan beberapa komponen dengan pedoman yang dimuat dalam Peraturan Menteri Pendidikan dan Kebudayaan Republik Indonesia nomor 103 tahun 2014 tentang pembelajaran pada pendidikan dasar dan pendidikan menengah serta Permendikbud RI nomor 104 tahun 2014 tentang penilaian hasil belajar oleh pendidik pada Pendidikan Dasar dan Pendidikan Menengah. Pedoman tersebut memuat rambu-rambu tentang prinsip-prinsip pengembangan perencanaan pembelajaran. Dalam rencana pelaksanaan pembelajaran pada kurikulum 2013 tidak mengenal standar kompetensi lagi, namun muncul istilah kompetensi inti. Kompetensi inti merupakan gambaran mengenai kompetensi utama yang dikelompokkan ke dalam aspek sikap, pengetahuan, dan keterampilan yang harus diperoleh siswa untuk suatu jenjang sekolah, kelas dan mata pelajaran. Kompetensi tersebut dapat diperoleh melalui pendekatan pembelajaran yang sesuai dengan kurikulum 2013.

Proses pembelajaran kurikulum 2013 dilaksanakan dengan menggunakan pendekatan ilmiah (scientific approach) yang menyentuh tiga ranah, yaitu sikap, pengetahuan, dan keterampilan. Pendekatan saintifik dalam pembelajaran sebagaimana dimaksud meliputi mengamati, menanya, mencoba atau mengumpulkan data, mengasosiasi atau menalar, dan mengkomunikasikan. Pendekatan saintifik menyediakan model pembelajaran project based learning, problem based learning, dan discovery learning.

Kurikulum 2013 lebih menekankan pada penilaian otentik (Authentic Assesment) karena memiliki relevansi yang kuat terhadap pendekatan saintifik. Penilaian tersebut mampu menggambarkan peningkatan hasil belajar siswa, baik dalam rangka mengamati, menanya, mencoba, menalar, mengkomunikasikan, dan sebagainya. Penilaiaan otentik cenderung fokus pada tugastugas kompleks atau konstektual, memungkinkan peserta didik untuk menunjukkan kompetensi mereka dalam pengaturan yang lebih otentik. Penilaian otentik harus mampu menggambarkan sikap, keterampilan, dan pengetahuan apa yang sudah atau belum dimiliki oleh siswa, bagaimana mereka menerapkan pengetahuannya, dalam hal apa mereka sudah atau belum mampu menerapkan perolehan belajar, dan sebagainya.

Penilaian otentik yang dianjurkan dalam kurikulum 2013 meliputi penilaian kinerja, penilaian proyek, penilaian portofolio, penilaian tertulis, dan penilaian diri. Salah satu penilaian yang dapat digunakan guru untuk mengetahui ketercapaian kompetensi yang menuntut siswa melakukan percobaan adalah penilaian kinerja. Penilaian kinerja (performance assessment) merupakan penilaian yang dilakukan dengan mengamati kegiatan siswa dalam melakukan sesuatu. Dengan penilaian kinerja maka guru dapat memperoleh informasi ketercapaian kompetensi siswa pada ranah sikap, pengetahuan, dan keterampilan secara terpadu.

Tujuan mata pelajaran fisika yang tercantum dalam Peraturan Menteri Pendidikan Nasional RI nomor 22 tahun 2006 tentang Standar Isi adalah agar siswa memiliki kemampuan: (1) membentuk sikap positif 
terhadap fisika dengan menyadari keteraturan dan keindahan alam serta mengagungkan kebesaran Tuhan Yang Maha Esa; (2) memupuk sikap ilmiah yaitu jujur, objektif, terbuka, ulet, kritis dan dapat bekerjasama dengan orang lain; (3) mengembangkan pengalaman untuk dapat merumuskan masalah, mengajukan dan menguji hipotesis melalui percobaan, merancang dan merakit instrumen percobaan, mengumpulkan, mengolah, dan menafsirkan data, serta mengkomunikasikan hasil percobaan secara lisan dan tertulis; (4) mengembangkan kemampuan bernalar dalam berpikir analisis induktif dan deduktif dengan menggunakan konsep dan prinsip fisika untuk menjelaskan berbagai peristiwa alam dan menyelesaikan masalah baik secara kualitatif maupun kuantitatif; (5) menguasai konsep dan prinsip fisika serta mempunyai keterampilan mengembangkan pengetahuan, dan sikap percaya diri sebagai bekal untuk melanjutkan pendidikan pada jenjang yang lebih tinggi serta mengembangkan ilmu pengetahuan dan teknologi.

Tujuan mata pelajaran fisika tersebut, jelas bahwa sikap ilmiah dan keterampilan justru sangat penting untuk dinilai. Prestasi belajar pada aspek sikap dan keterampilan pada mata pelajaran fisika tidak dapat diabaikan karena berdasarkan hakikatnya, fisika merupakan salah satu bagian dari IPA yang terbangun dari sikap, proses, dan produk. Mata pelajaran fisika di SMA dikembangkan dengan mengacu pada pengembangan yang ditunjukkan untuk mendidik siswa agar mampu mengembangkan observasi dan eksperimentasi serta berfikir taat asas. Hal ini didasari oleh tujuan fisika yakni mengamati, memahami, dan memanfaatkan gejala-gejala alam yang melibatkan zat (materi) dan energi (Raharjo dan Radiyono, 2008: 2). Kemampuan observasi dan eksperimentasi ini lebih ditekankan pada melatih kemampuan berfikir eksperimental yang mencangkup tata laksana percobaan dengan mengenal peralatan yang digunakan dalam pengukuran baik dalam laboratorium maupun di alam sekitar kehidupan siswa.

Berdasarkan observsi SMAN 2 Mejayan merupakan salah satu dari dua sekolah di kabupaten Madiun yang dijadikan sampel untuk melaksanaan kurikulum 2013. Berdasarkan wawancara dengan guru Fisika SMAN 2 Mejayan, perangkat pembelajaran yang disusun belum sepenuhnya sesuai dengan petunjuk pengembangan kurikulum 2013 dikarenakan pemahaman guru terhadap konten kurikulum 2013 masih kurang. Proses pembelajaran fisika belum menggunakan model pembelajaran yang sesuai dengan pendekatan saintifik. Perangkat pembelajaran yang disusun masih terpaku pada penilaian tertulis, sehingga belum nampak penilaian otentik yang sesuai dengan rambu-rambu kurikulum 2013. Hal ini menimbulkan kesulitan tersendiri pada guru untuk mengembangkan perangkat pembelajaran fisika yang berorientasi pada Kurikulum 2013. Fakta dalam proses pembelajaran fisika di SMAN 2 Mejayan masih didominasi dengan aspek produk belum melibatkan aspek proses. Dalam proses pembelajaran fisika, siswa jarang melakukan percobaan sehingga daya guna laboratorium fisika sekolah tidak optimal dan kompetensi sikap ilmiah dan keterampilan yang seharusnya dimiliki siswa belum tercapai. Siswa masih cenderung belum aktif dalam menyampaikan pendapat maupun menanggapi pertanyaan guru. Selain itu, rata-rata nilai fisika di sekolah tersebut masih kurang dari KKM.

Berdasarkan pada masalah yang terjadi di SMA Negeri 2 Mejayan melalui proses wawancara, analisis kinerja, dan analisis kebutuhan, perlu untuk dilakukan pengkajian. Penyusunan perangkat pembelajaran disertai proses pembelajaran yang belum optimal menjadikan prestasi belajar siswa kurang. Pelaksanaan proses belajar mengajar fisika perlu adanya pembelajaran dan metode mengajar tertentu yang sesuai serta sarana yang mendukung untuk membuat siswa aktif dalam proses pembelajaran. Dengan adanya hal tersebut maka diperlukan suatu perangkat pembelajaran yang pelaksanaannya dapat menumbuhkan aktivitas dan suasana belajar yang baru bagi siswa yaitu dengan melakukan pengembangan suatu perangkat pembelajaran yang tepat sesuai dengan tuntutan kurikulum 2013. 
Keberhasilan seorang guru dalam pembelajaran sangatlah diharapkan, untuk memenuhi tujuan tersebut diperlukan suatu persiapan yang matang. Sebelum guru mengajar, diharapkan mempersiapkan bahan yang mau diajarkan, mempersiapkan alat-alat peraga/ praktikum yang akan digunakan, mempersiapkan pertanyaan dan arahan untuk memancing peserta didik aktif belajar, mempelajari keadaan peserta didik, mengerti kelemahan dan kelebihan peserta didik, serta mempelajari pengetahuan awal peserta didik, kesemuanya ini akan terurai pelaksanaannya di dalam perangkat pembelajaran. Perangkat pembelajaran adalah sejumlah bahan, alat, media, petunjuk dan pedoman yang akan digunakan dalam proses pembelajaran (Suhadi, 2007: 24). Dalam Permendikbud nomor 65 tahun 2013 tentang Standar Proses Pendidikan Dasar dan Menengah disebutkan bahwa penyusunan perangkat pembelajaran merupakan bagian dari perencanaan pembelajaran. Perencanaan pembelajaran dirancang dalam bentuk silabus dan RPP yang mengacu pada standar isi. Selain itu, dalam perencanaan pembelajaran juga dilakukan penyiapan media dan sumber belajar, perangkat penilaian, dan skenario pembelajaran. Perangkat pembelajaran secara umum adalah sekumpulan media atau sarana yang digunakan oleh guru dan peserta didik dalam proses pembelajaran di kelas, yang harus dipersiapkan seorang guru dalam menghadapi pembelajaran di kelas yang terdiri dari silabus, Rencana Pelaksanaan Pembelajaran (RPP), lembar kegiatan, lembar penilaian, buku siswa dan buku pegangan guru, serta media pembelajaran. Prastowo (2012: 27) pentingnya perangkat pembalajaran dapat dirasakan oleh guru antara lain: a) menghemat waktu guru dalam mengajar, b) mengubah peran guru dari seorang pengajar menjadi seorang fasilitator, c) meningkatkan proses pembelajaran menjadi lebih efektif dan interaktif, d) sebagai pedoman bagi guru yang akan mengarahkan semua aktiftasnya dalam proses pembelajaran dan merupakan substansi kompetensi yang semestinya diajarkan kepada peserta didik, e) sebagai alat evaluasi pencapaian atau penguasaan hasil pembelajaran.

Perangkat pembelajaran tersebut harus disertai dengan model pembelajaran yang sesuai dan yang paling memungkinkan untuk diterapkan dalam pembelajaran yang sesuai dengan kurikulum 2013 dan hakikat fisika sehingga pembelajaran menjadi bermakna adalah Problem Based Learning (PBL) yang disertai dengan metode percobaan. Penerapan pembelajaran ini diharapkan dapat membawa siswa lebih aktif dalam kegiatan pembelajaran, mengembangkan keterampilan dan sikap ilmiah, meningkatkan kemampuan kognitif, dan dapat lebih memahami pelajaran fisika. PBL disertai percobaan perlu diterapkan dalam pembelajaran fisika agar terjadi pembelajaran yang bermakna. Siswa yang belajar memecahkan suatu masalah akan menerapkan pengetahuan yang dimilikinya atau berusaha mengetahui pengetahuan yang diperlukan. Belajar dapat semakin bermakna dan dapat diperluas ketika siswa berhadapan dengan situasi di mana konsep ditemukan ketika melakukan percobaan. Pembelajaran berdasarkan masalah dapat diterapkan untuk merangsang berpikir tingkat tinggi dalam situasi berorientasi masalah, termasuk di dalamnya belajar bagaimana belajar (Ibrahim, 2008: 5). Dalam situasi Problem Based Learning (PBL), siswa mengintegrasikan pengetahuan dan keterampilan secara simultan dan mengaplikasikannya dalam konteks yang relevan. Artinya, bahwa yang mereka lakukan sesuai dengan keadaan nyata sehingga masalah-masalah dalam aplikasi suatu konsep atau teori mereka akan temukan sekaligus selama pembelajaran berlangsung (Sardiman, 2011: 38).

Problem Based Learning (PBL) disertai dengan percobaan dapat meningkatkan kemampuan berpikir kritis, menumbuhkan inisiatif siswa dalam berkinerja, siswa terlibat aktif dalam mengumpulkan fakta, informasi, atau data yang diperlukan melalui percobaan yang dilakukannya, serta dapat mengembangkan hubungan interpersonal dalam bekerja kelompok. Sehingga pembelajaran bermakna ini akan dapat meningkatkan aktivitas siswa dalam belajar 
serta tercapai prestasi belajar pada kompetensi sikap, pengetahuan, dan keterampilan yang lebih baik.

Berdasarkan uraian latar belakang di atas, maka penelitian ini bertujuan untuk: 1) menghasilkan produk perangkat pembelajaran Fisika SMA berbasis Problem Based Learning (PBL) pada materi hukum Newton dan penerapannya kelas X SMAN 2 Mejayan dengan karakteristik kurikulum 2013, 2) menganalisis kelayakan perangkat pembelajaran Fisika SMA berbasis Problem Based Learning (PBL) pada materi hukum Newton dan penerapannya kelas X SMAN 2 Mejayan, dan 3) meningkatkan aktivitas belajar siswa kelas X SMAN 2 Mejayan menggunakan perangkat pembelajaran Fisika SMA berbasis Problem Based Learning (PBL).

\section{Metode Penelitian}

Metode penelitian yang digunakan yaitu penelitian Reseach and Development (R\&D) dengan model 4-D yang dikembangkan oleh Thiagarajan yang terdiri dari empat tahap yaitu: tahap define (pendefinisian), tahap design (perancangan), tahap develop (pengembangan), dan tahap disseminate (penyebaran). Penelitian ini mengembangkan perangkat pembelajaran Fisika SMA berbasis Problem Based Learning (PBL) pada materi hukum Newton dan Penerapannya.

Produk yang dikembangkan berupa perangkat pembelajaran Fisika berbasis Problem Based Learning (PBL) yang divalidasi oleh validator yang terdiri dari dua dosen ahli, dua guru, dan dua peer review. Subyek yang diteliti yaitu siswa kelas $\mathrm{X}$ SMAN 2 Mejayan tahun ajaran 2014/2015. Sampel pada uji coba terbatas sebanyak 16 siswa kelas X Matematika IPA-2 (MIA-2) dan teknik pengambilan sampel dilakukan dengan random sampling. Uji coba pemakaian produk adalah 32 siswa kelas X MIA-1 dan teknik pengambilan sampel dilakukan dengan classter sampling. Instrumen pengumpulan data pada penelitian yaitu lembar validasi, lembar observasi, dan angket. Lembar validasi digunakan untuk mengumpulkan data hasil review dari validator. Lembar observasi digunakan untuk mengetahui keterlaksanaan pembelajaran, menilai kompetensi sikap, keterampilan, dan aktivitas. Pengisian angket untuk memperoleh data analisis kebutuhan dan analisis kinerja.

\section{Hasil Penelitian dan Pembahasan}

Hasil penelitian yaitu produk berupa perangkat pembelajaran Fisika SMA berbasis Problem Based Learning (PBL) pada materi hukum Newton dan penerapannya. Hasil penelitian dan pembahasan sebagai berikut:

Tahap define dilakukan studi literatur berupa analisis konsep atau landasan teoritis, hasil penelitian terdahulu dan analisis kurikulum serta survei lapangan berupa analisis kebutuhan guru dan siswa yang sudah diterapkan di SMA Negeri 2 Mejayan. Bahan kajian yang dikembangkan adalah Kompetensi Dasar 3.4 yaitu "Menganalisis hubungan antara gaya, massa, dan gerakan benda pada gerak lurus" dan 4.4. yaitu "Merencanakan dan melaksanakan percobaan untuk menyelidiki hubungan gaya, massa, dan percepatan dalam gerak lurus". Kurikulum 2013 menyarankan bahwa proses pembelajaran yang tersusun dalam perangkat pembelajaran harus menggunakan pendekatan saintifik yang salah satunya adalah model pembelajaran Problem Based Learning (PBL) disertai metode percobaan. Penelitian Gamze Sezgin Selcuk, dkk (2013) dan Madhuchanda Mukherjee (2011) yang menyimpulkan bahwa PBL menghasilkan prestasi lebih baik daripada Pembelajaran Tradisional. Penelitian Xun Ge, et al (2010) menunjukkan bahwa model PBL secara signifikan dapat meningkatkan kemampuan dalam menyelesaikan masalah mekanisme pemodelan dan mendukung penalaran siswa. Hal ini didukung oleh teori belajar Piaget (Mundilarto, 2005: 24) yang menyatakan bahwa perkembangan kognitif siswa SMA telah berada pada tahap berfikir abstrak (usia 14 tahun ke atas) yang berarti sudah mampu berfikir hipotesis, proporsional, reflektif, logis, sintesis, imajinatif, kombinasional, etis, dan verbal serta memahami operasi-operasi yang bersifat abstrak. Menurut Bruner (Trianto, 2011: 26) 
yang terpenting dalam memperoleh pengetahuan adalah proses memperoleh pengetahuan tersebut bukan pada hasilnya. Pendekatan konstruktivisme, kegiatan belajar adalah kegiatan yang aktif di mana siswa membangun sendiri pengetahuannya (Sardiman, 2011: 38). Hal ini mendukung pelaksanaan pembelajaran berbasis PBL dengan kemampuan siswa dalam memecahkan masalah.

Kegiatan yang dilakukan pada survei lapangan adalah menyebarkan angket kebutuhan kepada 4 guru fisika dan 6 siswa kelas XI SMA Negeri 2 Mejayan. Hasil analisis kebutuhan guru disimpulkan bahwa dibutuhkan perangkat pembelajaran yang terdiri dari RPP, lembar penilaian kinerja, dan LKS yang sesuai pedoman kurikulum 2013. Perangkat pembelajaran tersebut dapat digunakan guru untuk melaksanakan pembelajaran Fisika sesuai tuntutan kurikulum 2013. Hasil analisis kebutuhan siswa disimpulkan bahwa dibutuhkan pembelajaran yang dapat membantu siswa untuk memahami materi hukum Newton dan penerapannya dengan cara melakukan pengamatan, membentuk kelompok, melakukan percobaan dengan paduan LKS, mengolah data percobaan, menyimpulkan, dan mengkomunikasikan.

Tahap Design melalui tiga tahap yaitu perancangan, pengumpulan bahan, dan penyusunan. Tahap perancangan dilaksanakan setelah dilakukan analisis kebutuhan awal yang menunjukkan diperlukannya pengembangan perangkat pembelajaran. Pembelajaran dalam perangkat yang dikembangkan dalam penelitian ini mengikuti sintak PBL (Nur, 2008: 11) antara lain: a) mengorientasikan siswa kepada masalah yaitu siswa mengamati gambar yang berkaitan dengan penerapan materi hukum Newton dan penerapannya dalam kehidupan sehari-hari; b) mengorganisasikan siswa untuk belajar yaitu siswa membentuk kelompok 4-5 orang kemudian merumuskan jawaban atas hasil pengamatan sebelum melakukan percobaan; c) membantu penyelidikan mandiri dan kelompok yaitu siswa melakukan percobaan untuk menguji jawabannya; d) mengembangkan dan menyajikan hasil karya serta memamerkannya yaitu siswa memasukkan data pengamatan ke dalam tabel, menganalisis atau mengolah data, membuat kesimpulan dan mengkomunikasikan hasil percobaan tersebut; e) menganalisis dan mengevalusi proses pemecahan masalah yaitu siswa melakukan refleksi atas percobaan yang telah dilakukan dan proses-proses yang mereka gunakan. Penyusunan desain RPP mengacu pada Permendikbud RI nomor 103 tahun 2014 tentang Kurikulum 2013 Sekolah Menengah Atas/ Madrasah Aliyah. LKS yang dikembangkan memiliki karateristik yang sesuai dengan tahapan pembelajaran PBL. Lembar penilaian kinerja mengacu pada Permendikbud RI nomor 104 tahun 2014 tentang penilaian hasil belajar oleh pendidik pada Pendidikan Dasar dan Pendidikan Menengah serta indikator mengacu pada Hibbard (2010: 17). Setelah tahap perancangan, pengumpulan bahan dan penyusunan maka dihasilkan draf I perangkat pembelajaran yang dikonsultasikan pada dosen pembimbing. Setelah diperbaiki maka draf I perangkat pembelajaran siap divalidasi untuk mengetahui kelayakannya.

Tahap Develop dilakukan tahapan validasi oleh ahli, guru, dan peer review kemudian uji coba terbatas dan uji coba lapangan.

\begin{tabular}{|c|c|c|c|c|c|c|}
\hline \multirow[t]{2}{*}{ Aspek } & \multicolumn{2}{|c|}{$\begin{array}{c}\text { Nilai Dosen } \\
\text { Ahli }\end{array}$} & \multirow{2}{*}{$\begin{array}{l}\text { Rata- } \\
\text { rata }\end{array}$} & \multirow[t]{2}{*}{$\begin{array}{l}\text { Skor } \\
\text { Ideal }\end{array}$} & \multirow{2}{*}{$\begin{array}{c}\text { Persen } \\
\text { tase }(\%)\end{array}$} & \multirow{2}{*}{$\begin{array}{l}\text { Kate } \\
\text { gori }\end{array}$} \\
\hline & 1 & 2 & & & & \\
\hline Silabus & 40 & 40 & 40 & 40 & 100 & SB \\
\hline RPP & 88 & 90 & 89 & 92 & 96,74 & SB \\
\hline LKS & 58 & 58 & 58 & 60 & 96,67 & SB \\
\hline Lembar & & & & & & \\
\hline Penilaian & 78 & 78 & 78 & 80 & 97,50 & SB \\
\hline Kinerja & & & & & & \\
\hline Jumlah & 264 & 266 & 265 & 272 & 97,43 & SB \\
\hline \multicolumn{7}{|c|}{ Tabel 2. Hasil Validasi oleh Guru } \\
\hline Aspek & \multicolumn{2}{|c|}{$\begin{array}{l}\text { Nilai Validasi } \\
\text { Guru }\end{array}$} & \multirow{2}{*}{$\begin{array}{l}\text { Rata- } \\
\text { rata }\end{array}$} & \multirow[t]{2}{*}{$\begin{array}{l}\text { Skor } \\
\text { Ideal }\end{array}$} & \multirow[t]{2}{*}{$\begin{array}{cc}0 & \text { Persen } \\
1 & \text { tase }(\%)\end{array}$} & \multirow{2}{*}{$\begin{array}{l}\text { Kate } \\
\text { gori }\end{array}$} \\
\hline & 1 & 2 & & & & \\
\hline Silabus & 40 & 40 & 40 & 40 & 100 & SB \\
\hline RPP & 90 & 90 & 90 & 92 & 97,83 & SB \\
\hline LKS & 60 & 59 & 59,5 & 60 & 99,17 & SB \\
\hline Lembar & & & & & & \\
\hline Penilaian & 78 & 79 & 78,5 & 80 & 98,13 & SB \\
\hline Kinerja & & & & & & \\
\hline Jumlah & 264 & 268 & 266 & 272 & 97,79 & SB \\
\hline
\end{tabular}


JURNAL INKUIRI

ISSN: 2252-7893, Vol 5, No. 3, 2016 (hal 1-11)

http://jurnal.fkip.uns.ac.id/index.php/sains

Tabel 3. Hasil Validasi oleh Peer Review

\begin{tabular}{|c|c|c|c|c|c|c|}
\hline \multirow[t]{2}{*}{ Aspek } & \multicolumn{2}{|c|}{$\begin{array}{c}\text { Validasi } \\
\text { Peer Review }\end{array}$} & \multirow[t]{2}{*}{$\begin{array}{l}\text { Rata- } \\
\text { rata }\end{array}$} & \multirow[t]{2}{*}{$\begin{array}{l}\text { Skor } \\
\text { Ideal }\end{array}$} & \multirow[t]{2}{*}{$\begin{array}{c}\text { Persen } \\
\text { tase }(\%)\end{array}$} & \multirow[t]{2}{*}{$\begin{array}{l}\text { Kata } \\
\text { gori }\end{array}$} \\
\hline & 1 & 2 & & & & \\
\hline Silabus & 40 & 40 & 40 & 40 & 100 & SB \\
\hline RPP & 89 & 83 & 86 & 92 & 93,48 & SB \\
\hline LKS & 57 & 57 & 57 & 60 & 95 & SB \\
\hline Lembar & 78 & 78 & 78 & 80 & 97,5 & SB \\
\hline Penilaian & & & & & & \\
\hline Kinerja & & & & & & \\
\hline Jumlah & 264 & 266 & 265 & 272 & 97,43 & SB \\
\hline
\end{tabular}

Hasil validasi oleh ahli adalah 97,43

dengan kategori sangat baik, guru adalah 97,79 dengan kategori "Sangat Baik, peer review adalah 97,43 dengan kategori "Sangat Baik". Secara keseluruhan dapat disimpulkan bahwa perangkat pembelajaran sudah layak untuk diuji coba secara terbatas dengan melakukan beberapa perbaikan.

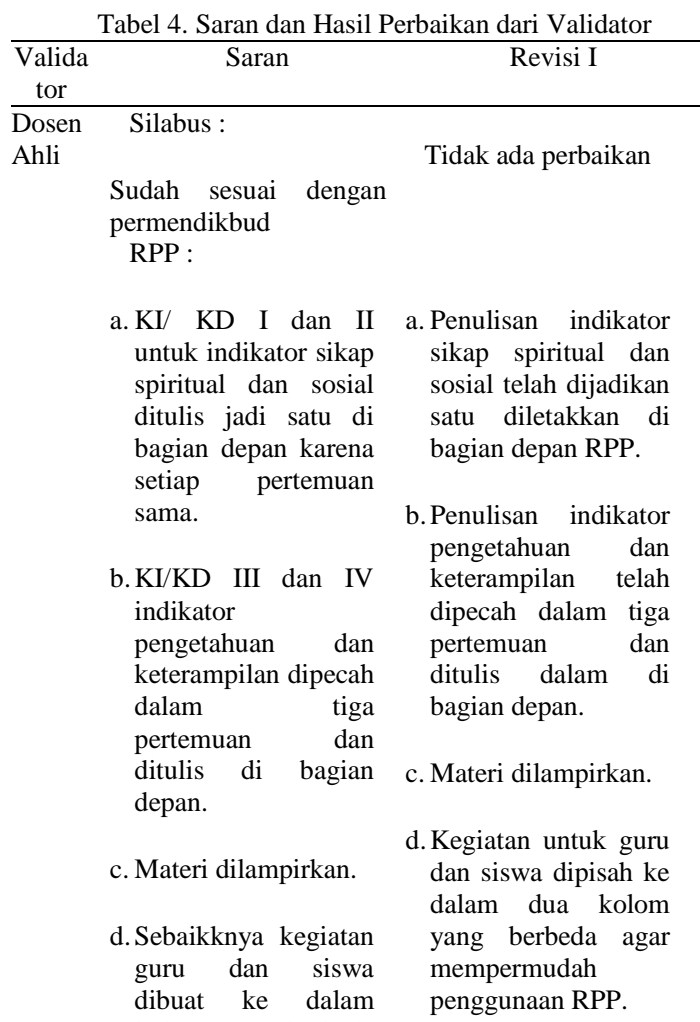

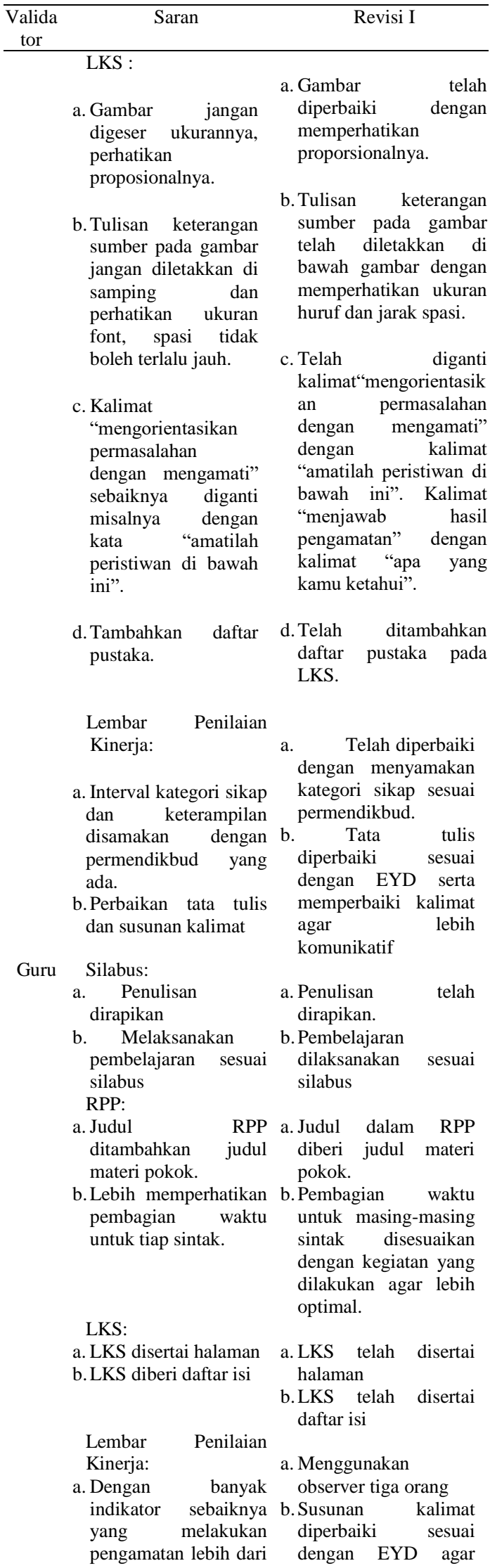




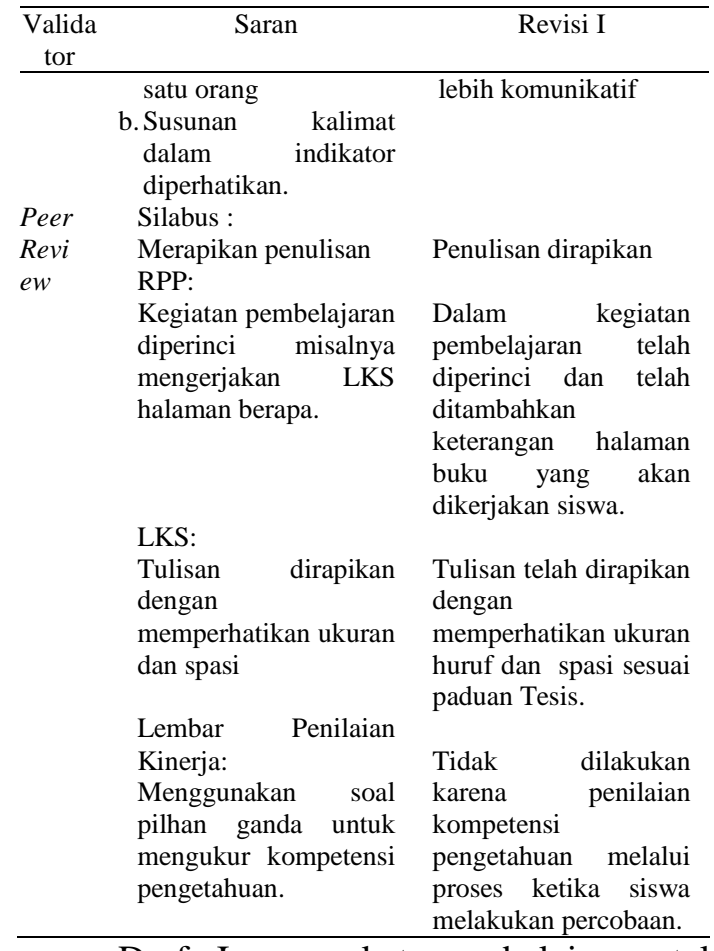

Draf I perangkat pembelajaran telah diperbaiki sesuai saran dan masukan dari para validator, sehingga diperoleh draf II perangkat pembelajaran yang siap diuji coba terbatas untuk mengetahui keterlaksanaan dan respon siswa terhadap pembelajaran berbasis PBL.

Uji coba terbatas perangkat pembelajaran berbasis PBL dilakukan pada 16 siswa kelas X MIA-2 SMA Negeri 2 Mejayan. Uji coba terbatas ini dilakukan oleh peneliti sebagai guru dan satu orang observer untuk mengamati keterlaksanaan pembelajaran.

Keterlaksanaan pembelajaran pada uji coba terbatas oleh guru memperoleh rata-rata dengan persentase 90,23 pada kategori "Sangat Baik" dan oleh siswa adalah 91,15 pada kategori "Sangat Baik".

Tabel 5. Hasil Penilaian Siswa Terhadap Pembelajaran

\begin{tabular}{clcccc}
\multicolumn{6}{c}{ pada Uji Coba Terbatas } \\
\hline \multirow{2}{*}{ No. } & \multicolumn{1}{c}{ Aspek } & Skor & $\begin{array}{c}\text { Skor } \\
\text { ideal }\end{array}$ & $\begin{array}{c}\text { Persen } \\
\text { tase }(\%)\end{array}$ & $\begin{array}{c}\text { Kate } \\
\text { gori }\end{array}$ \\
\hline 1 & Pelaksanaan PBL & 329 & 384 & 85,68 & SB \\
2 & Aktivitas Belajar & 277 & 320 & 86,56 & SB \\
3 & LKS & 228 & 256 & 89,06 & SB \\
4 & Sikap & 57 & 64 & 89,06 & SB \\
5 & Materi & 58 & 64 & 90,65 & SB \\
6 & Waktu & 49 & 64 & 76,56 & SB \\
Jumlah & 998 & 1.152 & 86,63 & SB \\
\hline
\end{tabular}

Angket respon menyatakan bahwa pencapaian skor aspek tertinggi adalah aspek materi diperoleh skor 90,65 pada kategori "Sangat Baik" membuktikan bahwa siswa lebih mudah memahami materi yang diberikan saat pembelajaran. Pencapaian skor aspek terendah adalah aspek waktu diperoleh skor 76,56 pada kategori "Baik" membuktikan bahwa alokasi waktu yang diberikan mencukupi untuk melakukan kegiatan pembelajaran tetapi guru tetap harus memperhatikan alokasi waktu agar pembelajaran terlaksana dengan sangat baik.

Draf II perangkat pembelajaran telah diujicobakan, langkah selanjutnya direvisi sesuai saran dan masukan dari siswa dan guru pada uji coba terbatas, sehingga diperoleh draf III perangkat pembelajaran.

\begin{tabular}{|c|c|c|}
\hline No. & Saran & Revisi Tahap II \\
\hline 1. & $\begin{array}{l}\text { Durasi waktu pada RPP } \\
\text { kurang sesuai dengan } \\
\text { kegiatan pembelajaran } \\
\text { yang dilaksanakan }\end{array}$ & $\begin{array}{l}\text { Menambahkan durasi waktu } \\
\text { pertemuan pertama pada } \\
\text { kegiatan pendahuluan } 5 \\
\text { menit menjadi } 10 \text { menit, } \\
\text { kegiatan inti } 55 \text { menit } \\
\text { menjadi } 50 \text { menit dan } \\
\text { pertemuan kedua dan ketiga } \\
\text { pada kegiatan pendahuluan } 5 \\
\text { menit menjadi } 15 \text { menit, } \\
\text { kegiatan inti } 120 \text { menit } \\
\text { menjadi } 110 \text { menit dan } \\
\text { mengarahkan siswa untuk } \\
\text { mengurangi mengobrol yang } \\
\text { tidak ada kaitannya dengan } \\
\text { proses pembelajaran untuk } \\
\text { mengintensifkan waktu. }\end{array}$ \\
\hline 2. & $\begin{array}{l}\text { Pertanyaan pada LKS } \\
\text { Hukum I Newton kurang } \\
\text { mendeskripsikan dan } \\
\text { keterangan panjang dan } \\
\text { massa benda kurang } \\
\text { lengkap. }\end{array}$ & $\begin{array}{l}\text { Ditambahkan kalimat "yang } \\
\text { berisi dirigen" dan } \\
\text { ditambahkan keterangan } \\
\text { "sepanjang } 40 \mathrm{~cm} \text { dan massa } \\
\text { bola bekel } 33 \text { gr dan massa } \\
\text { bola tenis } 3 \text { gr" }\end{array}$ \\
\hline 3. & $\begin{array}{l}\text { Keterangan kolom pada } \\
\text { lembar penilaian kinerja } \\
\text { kurang lengkap. }\end{array}$ & $\begin{array}{l}\text { Ditambahkan kolom dengan } \\
\text { keterangan "jumlah" }\end{array}$ \\
\hline
\end{tabular}

Uji coba lapangan menggunakan satu kelas yaitu kelas X MIA-1 sebagai kelas implementasi perangkat pembelajaran berbasis PBL yang telah dikembangkan. Data yang diperoleh dalam tahap uji coba lapangan adalah sebagai berikut:

Keterlaksanaan pembelajaran pada uji coba lapangan oleh guru memperoleh rata-rata dengan persentase 97,75 pada kategori "Sangat Baik" dan oleh siswa adalah 99,25 pada kategori "Sangat Baik". Kegiatan guru yang tidak dilakukan antara lain adalah mengingatkan siswa untuk menyajikan hasil percobaan, menanyakan tugas rumah pertemuan sebelumnya, dan meminta siswa untuk mengumpulkan. Kegiatan siswa yang 
tidak dilakukan adalah mengumpulkan tugas rumah berupa rangkuman pada materi yang sebelumnya.

Tabel 7. Hasil Penilaian Siswa Terhadap Pembelajaran pada Uji Lapangan

\begin{tabular}{clcccc}
\hline No. & Aspek & Skor & $\begin{array}{c}\text { Skor } \\
\text { ideal }\end{array}$ & $\begin{array}{c}\text { Persenta } \\
\text { se }(\%)\end{array}$ & $\begin{array}{c}\text { Kate } \\
\text { gori }\end{array}$ \\
\hline 1 & Pelaksanaan PBL & 676 & 768 & 88,02 & SB \\
2 & Aktivitas Belajar & 532 & 640 & 83,13 & SB \\
3 & LKS & 462 & 512 & 90,24 & SB \\
4 & Sikap & 108 & 128 & 84,34 & SB \\
5 & Materi & 115 & 128 & 89,84 & SB \\
6 & Waktu & 105 & 128 & 82,03 & SB \\
Jumlah & 1.998 & 2.304 & 86,71 & SB \\
\hline
\end{tabular}

Hasil angket saran siswa adalah: 1) siswa senang mengikuti kegiatan pembelajaran; 2) siswa lebih memahami materi yang diajarkan; 3) kegiatan mengamati peragaan oleh guru lebih mudah dipahami daripada mengamati gambar; 4) kegiatan percobaan yang dilakukan menarik dan menyenangkan; 5) siswa senang dapat mempresentasikan; 6) LKS yang diberikan menarik; 7) siswa senang berdiskusi dalam kelompok; dan 8) kegiatan pembelajaran yang telah dilakukan ini diharapkan dapat diulangi pada materi lainnya.

Hasil angket guru pada aspek pelaksanaan PBL, aktivitas belajar, LKS, sikap, materi dan waktu diperoleh persentase sebesar 100 dengan katagori "Sangat Baik". Hasil angket guru adalah memperhatikan alokasi waktu dalam melaksanakan pembelajaran dan perangkat pembelajaran dapat dikembangkan pada materi selanjutnya.

Prestasi belajar siswa yang diukur adalah kompetensi sikap, pengetahuan, dan keterampilan. Berikut uraian masing-masing prestasi belajar siswa:

Analisis penilaian kompetensi sikap siswa dinilai untuk mengetahui pencapaian sikap siswa dengan aspek yang dinilai adalah rasa ingin tahu, jujur, teliti, tekun, dan bertanggung jawab.

\begin{tabular}{|c|c|c|c|c|c|}
\hline Tabel & $\begin{array}{l}\text { Deskrips } \\
\text { ompetensi }\end{array}$ & $\begin{array}{l}\text { Data } \\
\text { ikap }\end{array}$ & Pencapai & \multicolumn{2}{|c|}{ Prestasi } \\
\hline Kegiatan & $\begin{array}{c}\text { Jumlah } \\
\text { Siswa }\end{array}$ & Mean & $\begin{array}{l}\text { Standar } \\
\text { Deviasi }\end{array}$ & $\begin{array}{l}\text { Mini } \\
\text { mum }\end{array}$ & $\begin{array}{c}\text { Maksi } \\
\text { mum }\end{array}$ \\
\hline 1 & 32 & 78,59 & 6,25 & 65 & 90 \\
\hline 2 & 32 & 82,97 & 5,94 & 70 & 90 \\
\hline 3 & 32 & 87,34 & 5,23 & 75 & 95 \\
\hline 4 & 32 & 88,91 & 5,35 & 75 & 95 \\
\hline Rata-rata & & & & 84,45 & \\
\hline
\end{tabular}

Tabel 8. menunjukkan bahwa rata-rata prestasi belajar pada kompetensi sikap adalah
84,5. Hal ini sejalan dengan penelitian Demirel dan Turan (2010) adanya peningkatan dalam belajar, sikap, metakognitif, dan motivasi pada kelas yang diberi perlakuan PBL dibanding dengan kelas kontrol.

Analisis penilaian kompetensi pengetahuan siswa dinilai untuk mengetahui pencapaian pengetahuan siswa. Aspek yang dinilai adalah merumuskan jawaban, mengumpulkan data, menganalisa data, dan membuat kesimpulan.

Tabel 9. Deskripsi Data Pencapaian Kompetensi Pengetahuan

\begin{tabular}{cccccc}
\multicolumn{7}{c}{$\begin{array}{c}\text { Kegia } \\
\text { tan }\end{array}$} & $\begin{array}{c}\text { Jumlah } \\
\text { Siswa }\end{array}$ & Mean & $\begin{array}{c}\text { Standar } \\
\text { Deviasi }\end{array}$ & $\begin{array}{c}\text { Mini } \\
\text { mum }\end{array}$ & $\begin{array}{c}\text { Maksimu } \\
\text { m }\end{array}$ \\
\hline 1 & 32 & 73,83 & 7,69 & 62,50 & 87,50 \\
2 & 32 & 78,13 & 8,98 & 62,50 & 93,75 \\
3 & 32 & 80,86 & 8,24 & 62,50 & 93,75 \\
4 & 32 & 83,01 & 11,36 & 62,50 & 93,75 \\
Rata-rata & & & & \multicolumn{2}{c}{78,91} \\
\hline
\end{tabular}

Tabel 9. menunjukkan bahwa rata-rata prestasi belajar pada kompetensi pengetahuan adalah 78,91. Hal ini sejalan dengan penelitian Akinoglu dan Tandogen (2006), Bilgin, Senocak, dan Sozbilir (2008), Olga Pierrakos, et al (2010) bahwa PBL dapat dapat memberikan pengaruh pada prestasi belajar.

Analisis penilaian kompetensi keterampilan siswa dinilai untuk mengetahui pencapaian keterampilan. Aspek yang dinilai adalah melakukan pengamatan, merumuskan jawaban, memilih dan merangkai alat dan bahan, mengumpulkan data, menganalisa data, membuat kesimpulan, menyajikan hasil percobaan, mengkomunikasikan.

Tabel 10. Deskripsi Data Pencapaian Kompetensi Keterampilan

\begin{tabular}{cccccc}
\multicolumn{7}{c}{$\begin{array}{c}\text { Segia } \\
\tan \end{array}$} & $\begin{array}{c}\text { Jumlah } \\
\text { Siswa }\end{array}$ & Mean & $\begin{array}{c}\text { Standar } \\
\text { Deviasi }\end{array}$ & Mini mum & $\begin{array}{c}\text { Maksi } \\
\text { mum }\end{array}$ \\
\hline 1 & 32 & 76,56 & 7,90 & 62,50 & 90,63 \\
2 & 32 & 80,76 & 8,22 & 65,63 & 96,88 \\
3 & 32 & 83,01 & 8,29 & 68,75 & 96,88 \\
4 & 32 & 84,48 & 9,27 & 65,63 & 96,88 \\
\multicolumn{2}{l}{ Rata-rata } & & & \multicolumn{2}{c}{81,20} \\
\hline
\end{tabular}

Tabel 10. menunjukkan bahwa ratarata prestasi belajar pada kompetensi keterampilan adalah 81,20. Hal ini sesuai dengan hasil penelitian Orla C. Kelly and Odilla E. Finlayson (2007) bahwa pendekatan pembelajaran PBL memberikan lingkup yang lebih untuk pengembangan keterampilan dan pemahaman tentang konsep dan proses eksperimental. 
Analisis hasil aktivitas dinilai untuk mengetahui pencapaian keterampilan dengan aspek yang dinilai adalah oral activities, listening activities, motor activities, writing activities, mental activities, dan emotional activities.

Tabel 11. Deskripsi Data Pencapaian Aktivitas Siswa

\begin{tabular}{|c|c|c|c|c|c|}
\hline \multicolumn{2}{|c|}{ Kegia Jumlah } & Mean & $\begin{array}{l}\text { Standar } \\
\text { Deviasi }\end{array}$ & Minimum & Maksimum \\
\hline 1 & 32 & 17,09 & 2,56 & 12 & 22 \\
\hline 2 & 32 & 18,09 & 1,73 & 15 & 22 \\
\hline 3 & 32 & 18,81 & 1,89 & 15 & 23 \\
\hline 4 & 32 & 19,34 & 1,98 & 16 & 23 \\
\hline \multicolumn{2}{|c|}{ Rata-rata } & & & \multicolumn{2}{|c|}{18,33} \\
\hline
\end{tabular}

Tabel 11. menunjukkan bahwa hasil rata-rata aktivitas belajar siswa adalah 18,33 dengan kategori "Baik". Selama proses pembelajaran PBL bahwa aktivitas siswa mengalami peningkatan sebesar $13,17 \%$. Hal ini sesuai dengan hasil penelitian Sharifah Norul Akmar SZ dan Lee Siew Eng (2005) yang menyimpulkan bahwa model Pembelajaran Berbasis Masalah mengindikasikan pengaruh positif terhadap kemampuan, aktivitas, dan persepsi terhadap matematika.

Tidak ada revisi draf III perangkat pembelajaran setelah uji coba lapangan, selanjutnya diperoleh perangkat pembelajaran fisika berbasis PBL pada materi hukum Newton dan penerapannya yang siap disebarluaskan.

Tahap disseminate penyebaran dilakukan setelah diperoleh produk berupa perangkat pembelajaran fisika berbasis PBL yang valid dan efektif untuk meningkatkan aktivitas belajar siswa. Penyebaran produk berupa perangkat pembelajaran fisika berbasis PBL dilakukan pada 10 guru Fisika SMA yang mengajar siswa kelas $\mathrm{X}$ di kota/kabupaten Madiun di Provinsi Jawa Timur. Rata-rata skor total diperoleh 19,6 dari skor maksimum 20 yaitu $98 \%$ dengan kategori sangat baik.

\section{Kesimpulan dan Rekomendasi}

Berdasarkan hasil analisis data dan pembahasan dalam penelitian ini, dapat disimpulkan bahwa: 1) Perangkat pembelajaran Fisika berbasis Problem Based Learning (PBL) pada materi hukum Newton dan penerapannya kelas X SMAN 2 Mejayan yang dikembangkan dengan karakterisik kurikulum 2013 adalah berdasarkan komponen pembelajaran scientific dengan model Problem Based Learning (PBL) disertai metode percobaan menggunakan teori belajar Bruner, Konstruktivisme, dan Piaget; 2) Kelayakan perangkat pembelajaran berbasis Problem Based Learning (PBL) pada materi hukum Newton dan penerapannya kelas X SMAN 2 Mejayan adalah layak digunakan berdasarkan penilaian oleh dosen ahli 97,43 dengan kategori sangat baik, guru 97,79 dengan kategori sangat baik, dan peer review 97,43 dengan kategori sangat baik. Hasil penilaian siswa terhadap pembelajaran pada uji coba terbatas yang terdiri dari 16 orang siswa di SMAN 2 Mejayan adalah 86,63 dengan kategori sangat baik. Hasil penilaian siswa terhadap pembelajaran pada uji coba lapangan yang terdiri dari 32 orang siswa di SMAN 2 Mejayan adalah 86,71 dengan kategori sangat baik. Hasil penilaian guru pada tahap penyebaran yang terdiri dari 10 orang guru di kota/kabupaten Madiun adalah 98 dengan kategori sangat baik; 3) implementasi perangkat pembelajaran Fisika berbasis Problem Based Learning (PBL) pada materi Hukum Newton dan penerapannya dapat meningkatkan aktivitas belajar siswa kelas $\mathrm{X}$ SMAN 2 Mejayan dengan peningkatan sebesar $13,17 \%$. Sumbangan ide dan wawasan berkaitan dengan peningkatan aktivitas belajar siswa yaitu: (1) Kepada guru mata pelajaran Fisika hendaknya mengembangkan perangkat pembelajaran dengan menggunakan pembelajaran yang berbasis scientific salah satunya Problem Based Learning (PBL) agar sesuai dengan karakteristik siswa dan kebutuhan kurikulum 2013 agar siswa dapat memahami konsep fisika dengan baik dan melatih siswa terbiasa dengan penyelesaian masalah melalui kegiatan pengamatan dan percobaan sehingga dapat meningkatkan aktivitas belajar siswa. Kegiatan percobaan yang ada dalam pembelajaran hendaknya benar-benar dilaksanakan; (2) Kepada peneliti yang lain disarankan bahwa hasil penelitian ini dapat digunakan sebagai acuan dalam penelitian dan pengembangan sejenis pada 
materi yang berbeda untuk meningkatkan aktivitas belajar siswa. Pada tahap penyebaran, peneliti dapat menyebarkan produk perangkat pembelajaran yang dikembangkan lebih luas lagi agar produk mudah dikenal oleh banyak peminat untuk digunakan dalam proses pembelajaran fisika.

\section{Daftar Pustaka}

Akinoglu, O \& Tandogan, R.O. (2006) The Effects of Problem-Based Active Learning in Science Education On Students Academic Achievment, Attitude and Concept Learning. Eurasia Journal of Mathematics, Science \& Technology Education, 3 (1): 71-81.

Bilgin, I, Senocak, E, Sozbilir, M. (2009) The Effects of Problem-Based Learning Instruction on University Students' Performance of Conceptual and Quantitative Problems in Gas Consepts. Eurasia Journal of Mathematics, Science and Technology Education, 5(2): 153-164.

Demirel, Melek and Turan, Belma (2010) The Effects of Problem Based Learning on Achievement, Attitude, Metacognitive Awareness and Motivation. H.U. Journal of Education, 38: 55-66.

Gamze Sezgin Selcuk, Serap Caliskan, Mehmet Sahin (2013) A Comparison Of Achievement in Problem-Based, Strategic and Traditional Learning Classes in Physics. International Journal on New Trends in Eti, 14(4): 154-164.

Hibbard (2010) Performance Assessment in The Science Classroom. New York: Glencoe.

Ibrahim, M. (2008) Model Pengembangan Perangkat Pembelajaran Menurut Jerold E. Kemp \& Thiagarajan. Surabaya: FPMIPA Universitas Negeri Surabaya.

Madhuchanda Mukherjee (2011) Effectivenes of Problem Based Learning Model (CAM) in Terms of Achievement in Science of Class VIII. International Referred Reseaach Journal, 2 (18).

Mundilarto (2005) Kapita Selekta Pendidikan Fisika. Yogyakarta: Fakultas Matematika dan Ilmu Pengetahuan Alam Universitas Negeri Yogyakarta.

Nur, M. (2008) Model Pembelajaran Berdasarkan Masalah. Surabaya: Pusat Sains dan Matematika Sekolah Universitas Negeri Surabaya.
Olga Pierrakos, Anna Zilberberg, dan Robin Anderson (2010) Understanding Undergraduate Research Experiences through the Lens of Problem-based Learning. Interdisciplinary Journal of Problem-based Learning, 2 (4):35-62.

Orla C. Kelly and Odilla E. Finlayson (2007) Providing Solution through ProblemBased Learning for the Undergraduate 1st year chemistry laboratory. Journal Chemistry Education Research and Practice, 8 (3): 347-361.

Prastowo, A. (2012) Panduan Kreatif Membuat Bahan Ajar Inovatif: Menciptakan Metode Pembelajaran yang Menarik dan Menyenangkan. Yogyakarta: DIVA Press (Anggota IKAPI).

Raharjo, Trustho dan Radiyono, R. (2008) Fisika Mekanika. Surakarta: LPP UNS dan UNS Press.

Sardiman (2011) Interaksi dan Motivasi Belajar Mengajar. Jakarta: PT Raja Grafindo Persada.

Sharifah Norul Akmar SZ dan Lee Siew Eng (2005) Integrating Problem-Based-Learning (PBL) in Mathematics Method Course. Journal of Problem-based Learning, 3 (1).

Suhadi (2007) Petunjuk Perangkat Pembelajaran. Surakarta: Universitas Muhammadiyah.

Trianto (2011) Model Pembelajaran Terpadu. Jakarta: PT Bumi Aksara.

Xun Ge, Lourdes G. Planas, dan Nelson Er (2010) A Cognitive Support System to Scaffold Students' Problem-based Learning in a Web-based Learning Environment. Interdisciplinary Journal of Problembased Learning, 4 (4): 30-56. 